Journal of Science

and Engineering

Full Paper

\section{Analisa Hidrolis Jaringan PiPA Distribusi Utama Dan Distribusi Bagi Pada Sistem PenyediaAn AIR Minum (SPAM) IKK Wasile TIMUR}

Article history

Received

2 Januari 2018

Received in revised form

2 Pebruari 2018

Accepted

5 Mei 2018

*Corresponding author zulkarnainmisbah@gmail.com

a,b,c Universitas Khairun, Ternate, Indonesia

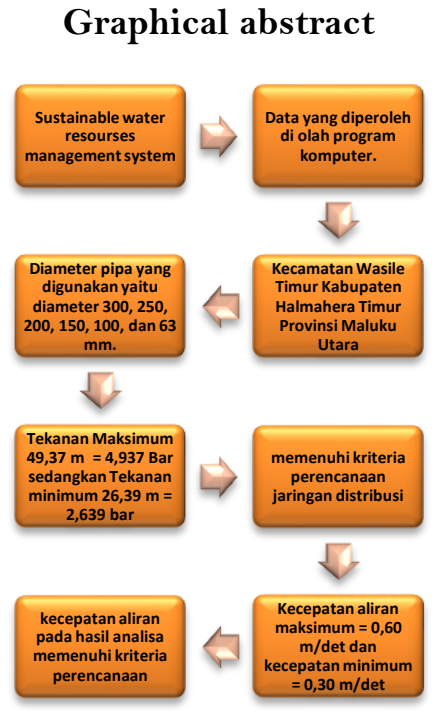

\begin{abstract}
The existing water resources need to be sustainably managed. Sustainable water resource management system is a managed and managed water resources management system that fully contributes to current and future societal and economic goals while maintaining its ecological sustainability. This research was conducted by direct observation in the field. Then the data obtained from the field in though by using a computer program. This research activity was conducted in East Wasile Sub-district of East Halmahera Regency of North Maluku Province. The results of this study indicate that the diameter of the pipe used is $300 \mathrm{~mm}$ diameter, $250 \mathrm{~mm}$, $200 \mathrm{~mm}, 150 \mathrm{~mm}, 100 \mathrm{~mm}$, and $63 \mathrm{~mm}$. From the variation of the pipe obtained Maximum pressure $49.37 \mathrm{~m}$ or equal to $4.937 \mathrm{bar}$ while minimum pressure of $26.39 \mathrm{~m}$ or equal to $2,639 \mathrm{bar}$. The pressure of the analysis result meets the criteria of distribution network planning that is maximum $9.0-12.4$ bar and minimum $0.5-1.0$ bar. Maximum flow velocity of $0.60 \mathrm{~m} / \mathrm{s}$ and a minimum speed of $0.30 \mathrm{~m} / \mathrm{s}$ flow velocity on the analysis results meets the planning criteria which according to the provisions of a maximum of $2.5 \mathrm{~m} / \mathrm{s}$ and a minimum of $0.25 \mathrm{~m} / \mathrm{s}$.
\end{abstract}

Keywords: distribution network, hydraulic analysis, epanet 2.0

\begin{abstract}
Abstrak
Sumber daya air yang ada perlu dikelola secara berkelanjutan.Sistem pengelolaan sumberdaya air berkelanjutan sustainable water resourses management system merupakan sistem pengelolaan sumber daya air yang didesain dan dikelola serta berkontribusi penuh terhadap tujuan masyarakat (sosial dan ekonomi) saat ini dan masa yang akan datang, dengan tetap mempertahankan kelestarian aspek ekologisnya. Penelitian ini dilaksanakan dengan cara peninjauang langsung di lapangan. Kemudian data yang diperoleh dari lapangan di olah dengan menggunakan program komputer. Kegiatan penelitian ini dilaksanakan di Kecamatan Wasile Timur Kabupaten Halmahera Timur Provinsi Maluku Utara. Hasil penelitian ini menunjukkan bahwa Diameter pipa yang digunakan yaitu diameter $300 \mathrm{~mm}, 250 \mathrm{~mm}, 200 \mathrm{~mm}, 150 \mathrm{~mm}, 100 \mathrm{~mm}$, dan $63 \mathrm{~mm}$. Dari variasi Pipa tersebut didapat Tekanan Maksimum 49,37 $\mathrm{m}$ atau sama dengan 4,937 Bar sedangkan Tekanan minimum sebesar 26,39 $\mathrm{m}$ atau sama dengan 2,639 bar. Tekanan dari hasil analisis memenuhi kriteria perencanaan jaringan distribusi yaitu maksimum 9,0 - 12,4 bar dan minimum 0,5 - 1,0 bar. Kecepatan aliran Maksimum sebesar 0,60 m/det dan kecepatan minimum sebesar $0,30 \mathrm{~m} /$ det kecepatan aliran pada hasil analisa memenuhi kriteria perencanaan dimana menurut ketentuan yaitu maksimum $2,5 \mathrm{~m} /$ det dan minimum sebesar $0,25 \mathrm{~m} /$ det.
\end{abstract}

Kata kunci: Jaringan distribusi, analisa hidrolis, epanet 2.0

(C) 2018 Penerbit Fakultas Teknik Unkhair. All rights reserved 


\subsection{INTRODUCTION}

Air merupakan hal paling penting dalam kehidupan. Dalam setiap aktifitas manusia mutlak membutuhkan air bersih. Untuk itu diperlukan adanya air bersih yang secara kualitas memenuhi standart yang berlaku dan secara kuantitas maupun kontinuitas harus dapat memenuhi kebutuhan masyarakat di suatu wilayah sehingga aktifitas dapat berjalan dengan baik.

Sumber daya air yang ada perlu dikelola secara berkelanjutan. Sistem pengelolaan sumber daya air berkelanjutan atau sustainable water resourses management system merupakan sistem pengelolaan sumber daya air yang didesain dan dikelola serta berkontribusi penuh terhadap tujuan masyarakat (sosial dan ekonomi) saat ini dan masa yang akan datang, dengan tetap mempertahankan kelestarian aspek ekologisnya.

Kecamatan Wasile Timur yang memiliki jumlah penduduk 10.385 jiwa Pada tahun 2016 merupakan salah satu Kecamatan yang mempunyai sumber daya air yang cukup melimpah maka dari itu perlu dikelola secara berkelanjutan.

Sungai oboi yang terletak di Desa Tutuling Jaya merupakan salah satu sumber air baku dengan debit 1.043 liter/detik yang sudah dimanfaatkan untuk keperluan air bersih di desa tutuling jaya yang saat ini hanya melayani 190 Sambungan Rumah (SR) atau 950 jiwa. Sungai tersebut terletak kurang lebih 2,5 Km dari pemukiman desa Tutuling Jaya. Sungai tersebut Berada di ketinggian kurang lebih 100 mdpl. Dilihat dari pelayanan yang sangat sedikit untuk debit air yang sangat besar yaitu 1.043 liter/detik. Maka diperlukan perencanaan jaringan air bersih dengan sistem pengaliran gravitasi karena daerah pelayanan yang relatif datar dengan ketinggian daerah pelayanan rata - rata 15 mdpl. untuk membantu proses analisis pergerakan aliran air pada jaringan perpipaan sebelum proses pelaksanaan pekerjaan pemasangan jaringan air bersih, kita bisa menggunakan program Epanet 2.0. Epanet merupakan program yang dapat membantu dalam merencanakan suatu sistem jaringan distribusi perpipaan, dimana program ini dapat menganalisa suatu model jaringan distribusi apakah telah sesuai dengan perencanaan atau tidak, bisa juga kita gunakan untuk menganalisa masalah-masalah yang terjadi setelah pemasangan jaringan air bersih. Program Epanet 2.0 sangatlah penting untuk digunakan pada saat proses perencanaan sistem jaringan air bersih. Tujuan yang akan dicapai dalam penelitian ini yaitu untuk mengetahui banyaknya zona - zona pelayanan di kecamatan wasile timur, mengetahui kebutuhan air total dan di masing masing zona pelayanan dan untuk mengetahui diameter pipa distribusi utama dan distribusi bagi yang memenuhi kriteria teknis.

Usaha penyediaan dan pendistribusian air bersih kepada masyarakat harus selalu diperhatikan kualitasnya, maka dari itu air bersih harus memenuhi persyaratan yang telah ditentukan. Kriteria yang kemudian digunakan sebagai pedoman dalam mendimensi, serta mendesain sistem jaringan tersebut antara lain adalah :

1. Tinggi tekanan pada titik atau node jaringan diistibusi utama terjauh minimum 5 meter.

2. Tinggi tekanan yang diijinkan pada titik atau node maksimum 90 meter.

3. Jenis pipa yang digunakan adalah HDPE.

4. Sistem jaringan yang digunakan dengan pola terbuka.

5. Evaluasi jaringan dengan menggunakan program Epanet versi 2.0

Tabel 1 Kriteria pipa transmisi dan distribusi menurut Kep Men PU No.18 Tahun 2007

\begin{tabular}{|c|c|c|c|}
\hline No & Uraian & $\begin{array}{c}\text { Kriteria } \\
\text { Pipa Transmisi }\end{array}$ & $\begin{array}{c}\text { Kriteria } \\
\text { Pipa Distribusi }\end{array}$ \\
\hline 1 & Debit Perencanaan (Qmax) & F max x Q retara & $F \max \times Q$ retara \\
\hline 2 & Faktor Harian Maksimum (Fmax) & $1,10-1,50$ & $1,15-3$ \\
\hline 3 & Jenis saluran & Pipa atau Terbuka & - \\
\hline 4 & $\begin{array}{l}\text { Kecepatan Aliran dalam Pipa } \\
\text { a. Kecepatan minimum (Vmin) } \\
\text { b. Kecepatan maksimum (Vmax) }\end{array}$ & $0,3-0,6 \mathrm{~m} / \mathrm{s}$ & $0,3-0,6 \mathrm{~m} / \mathrm{s}$ \\
\hline & $\begin{array}{l}\text { PVC } \\
\text { DCIP }\end{array}$ & $\begin{array}{c}0,3-4,5 \mathrm{~m} / \mathrm{s} \\
6,0 \mathrm{~m} / \mathrm{s}\end{array}$ & $\begin{array}{c}0,3-4,5 \mathrm{~m} / \mathrm{s} \\
6,0 \mathrm{~m} / \mathrm{s}\end{array}$ \\
\hline 5 & $\begin{array}{l}\text { Tekanan Air dalam Pipa } \\
\text { a.Tekanan minimum (Hmin) } \\
\text { b.Tekanan maksimum (Hmaks) }\end{array}$ & $1 \mathrm{~atm}$ & 0,5-1,0 atm, pada titik jangkauan terjauh \\
\hline & Pipa PVC & $6-8 \mathrm{~atm}$ & $6-8 \mathrm{~atm}$ \\
\hline & Pipa DVC & $10 \mathrm{~atm}$ & $10 \mathrm{~atm}$ \\
\hline & Pipa PE 100 & $12,4 \mathrm{~atm}$ & $12,4 \mathrm{~atm}$ \\
\hline & Pipa PE 80 & $9,0 \mathrm{~atm}$ & $9,0 \mathrm{~atm}$ \\
\hline 6 & Kecepatan Saluran Terbuka & & \\
\hline
\end{tabular}




\begin{tabular}{clcl}
\hline & a) Kecepatan minimum (Vmin) & $0,6 \mathrm{~m} / \mathrm{s}$ & \\
& b) Kecepatan Maksimum (Vmaks) & $1,5 \mathrm{~m} / \mathrm{s}$ & - \\
\hline 7 & Kemiringan Saluran Terbuka & $0,005-0,001$ & - \\
\hline 8 & Tinggi bebas saluran terbuka & $15 \mathrm{~cm}($ minimum $)$ & \\
\hline 9 & Kemiringan tebing terhadap dasar saluran & $45^{\circ}$ untuk trapesium & \\
\hline
\end{tabular}

Hasil yang didapat dari simulasi hidrolik dan performansi jaringan menggunakan EPANET 2.0 yaitu keseimbangan jaringan, arah aliran, head yang terjadi. Selain itu, analisa sebuah jaringan pipa dengan menggunakan EPANET 2.0 dapat membantu kita untuk memecahkan beberapa masalah diantaranya:

1 Analisa terhadap jaringan baru

2 Analisa terhadap energi dan biaya

3 Optimalisasi dari penggunaan air, kualitas air dan tekanan

Untuk menjalankan program ini diperlukan input data yang mendukung, sehingga dihasilkan output yang menunjukkan performansi jaringan tersebut. Input yang diperlukan pada program ini yaitu:

1. Input komponen yang mendukung sebuah sistem jaringan pipa yang meliputi pipa, pompa dan reservoir.

2. Input berupa node yang menghubungkan masing-masing pipa sehingga membentuk sebuah sistem jaringan pipa.

3. Input berupa nomor masing-masing komponen baik pipa, node, pompa, dan reservoir.

4. Input yang menunjukkan karakteristik masing-masing komponen yang meliputi diameter, panjang, kekasaran bahan pipa dan karakteristik pompa.

5. Input persamaan yang akan digunakan yang merupakan karakteristik dari hidrolik.

Dengan menggunakan data yang berupa input seperti diatas maka analisa hidrolik dapat dilakukan.

\subsection{METODE PENELITIAN}

Penelitian ini dilaksanakan dengan cara peninjauan langsung di lapangan.Kemudian data yang diperoleh dari lapangan di olah dengan menggunakan program komputer.

\subsection{Tahap dan Prosedur Penelitian}

1. Tahap I ( Tahap Persiapan)

Tahap ini meliputi persiapan alat - alat yang akan di gunakan untuk proses pengambilan data.

2. Tahap II (Tahap pengambilan Data)

Pada Tahap Ini peneliti mulai mengambil data - data yang diperlukan untuk keperluan proses analisis baik data yang di ambil di lapangan ataupun data yang di ambil dari Badan pusat statistik atau yang lainnya.

Langkah - langkah pengambilan data air baku.

1. Mengukur penampang basah sungai dengan cara mengukur lebar sungai kemudian dari hasil pengukuran lebar dibagi 5 untuk acuan jarak pengukuran kedalaman sungai.

2. Mengukur kedalaman sungai sesuai jarak yang sudah di tentukan pada saat pengukuran lebar sungai.

3. Setelah mengukur lebar dan kedalaman sungai selanjutnya mengukur jarak 1 meter searah aliran sungai untuk mengetahui kecepatan aliran.

4. Menyiapkan stopwatch kemudian menghanyutkan Styrofoam pada jarak 1 meter dengan menjalankan waktu pada stopwatch dan stop stopwatch pada saat Styrofoam mencapai jarak 1 meter.

5. Setelah dilakukan pengukuran luas penampang basah dan kecepatan aliran selanjutnya sudah bisa di hitung debit sungai yang akan di manfaatkan sebagai air baku.

6. Hasil pengukuran debit sumber air baku.

Tabel 2 Hasil pengukuran debit sumber air baku

\begin{tabular}{crr}
\hline No & $\begin{array}{c}\text { Lebar Sungai } \\
(\mathbf{b})\end{array}$ & $\begin{array}{c}\text { Kedalaman } \\
(\mathbf{h})\end{array}$ \\
\hline 1 & 0 & 0.8 \\
2 & 0.375 & 0.89 \\
3 & 0.375 & 1.5 \\
4 & 0.375 & 0.91 \\
5 & 0.375 & 0.87 \\
Total & $\mathbf{1 . 5}$ & $\mathbf{4 . 9 7}$ \\
\hline
\end{tabular}


3. Tahap III (Tahap analisis )

Pada Tahap ini semua data yang di perlukan untuk proses analisis sudah harus terkumpul semua, kemudian peneliti menganalisis data - data yang telah terkumpul untuk mendapat kesimpulan.

4. $\quad$ Tahap IV (Tahap Pengambilan Kesimpulan)

Pada Tahap ini dibuat suatu kesimpulan berdasarkan hasil analisis yang telah dilakukan sebagai jawaban dari tujuan yang akan dicapai pada penelitian ini.

\subsection{HASIL DAN PEMBAHASAN}

\subsection{Proyeksi Jumlah Penduduk}

Perhitungan proyeksi jumlah penduduk dapat di dihitung dengan 3 metode, yaitu metode geometrik, metode aritmatik dan metode least square setelah diketahui hasil dari perhitungan masing - masing metode, ditentukan nilai standart deviasi terkecil dari masing - masing metode untuk menentukan metode mana yang akan dipakai untuk menentukan kebutuhan air. Perencanaan jaringan distribusi air bersih direncanakan dalam kurun waktu 15 tahun kedepan yaitu dari tahun 2018 - 2032. Daerah perencanaan diproyeksikan yaitu 1 kecamatan yang terdiri dari 6 Desa.

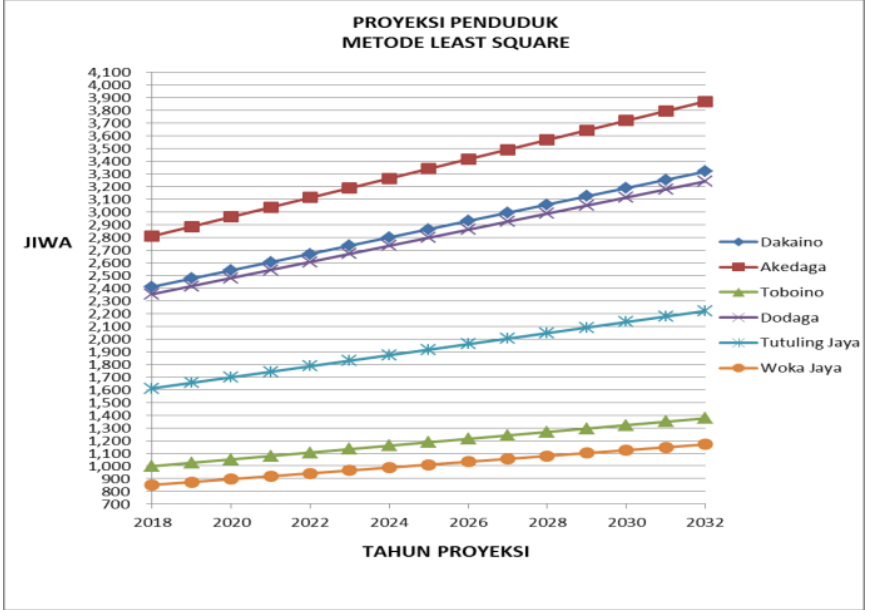

(a)

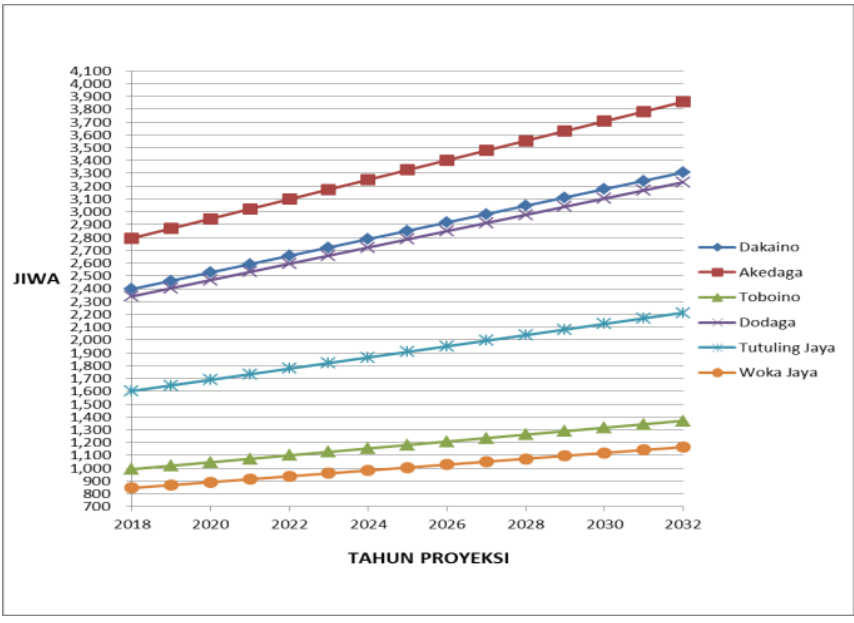

(b)

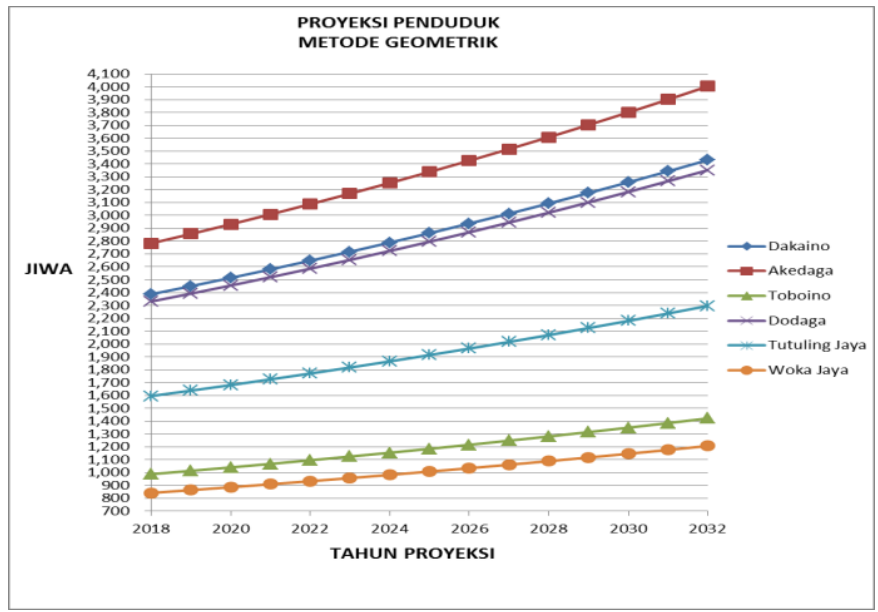

(c)

Gambar 2 Grafik Hasil Proyeksi Jumlah Penduduk (a) Metode least square, (b) Metode Aritmatik dan (c) Metode Geometrik 
Dari tabel diatas dapat diketahui bahwa Hasil dari perhitungan porsentase pertumbuhan penduduk rata - rata tertinggi didapat dari hasil perhitungan dengan metode geometrik yaitu antara $2.61 \%-2.63 \%$ sedangkan angka pertumbuhan penduduk terrendah yaitu hasil dari perhitungan dengan metode least square yaitu antara $2.31 \%-$ 2.33\% Kemudian setelah didapat hasil dari proyeksi penduduk dari ketiga metode selanjutnya dicari nilai Standar Deviasi yang paling kecil untuk menghitung kebutuhan air sampai tahun 2032. Pada ketiga metode proyeksi yang digunakan didapat nilai standart deviasi yang terendah pada metode geometrik maka metode yang digunakan untuk menghitung kebutuhan air sampai tahun 2032 adalah metode geometrik.

\subsection{Proyeksi Kebutuhan Air}

Proyeksi kebutuhan air sangat diperlukan untuk mengetahui kebutuhan air pada masa periode terutama pada akhir periode dimana hasil dari perhitungan kebutuhan air pada akhir periode yang akan digunakan untuk analisa hidrolis jaringan distribusi yang di rencanakan. Perhitungan proyeksi kebutuhan air di hitung berdasarkan tabel standart kebutuhan air yang di kutip dari Dirjen Cipta Karya Departemen Pekerjaan umum (DPU) Tahun 1995, dimana kecamatan Wasile Timur masih masuk dalam kategori kota kecil karena jumlah penduduk kecamatan Wasile Timur masih di bawah 100.000 jiwa. Hasil perhitungan meliputi :

1. Hasil Perhitungan Tingkat Pelayanan (Target) $100 \%$

2. Hasil Perhitungan kebutuhan air Domestik untuk Sambungan rumah (SR) 100 Liter/orang/hari dan Hidran umum (HU) 30 liter/orang/hari

3. Hasil perhitungan Kebutuhan air non domestik untuk kategori kota kecil yaitu $20 \%-30 \%$ X Kebutuhan air Domestik.

4. Hasil perhitungan Jumlah Jiwa/ SR $=5$ Dan Jumlah Jiwa/HU $=100$

5. Hasil perhitungan kebutuhan hari rata-rata

6. Hasil perhitungan kebutuhan hari maksimum

7. Kehilangan air untuk sistem baru $20 \%$ untuk sistem lama $30 \%-50 \%$

8. Hasil perhitungan Kebutuhan Jam puncak

Perhitungan kebutuhan air Desa Dakaino pada tahun 2032

1. Jumlah penduduk : 3431 Jiwa

2. Penduduk yang dilayani melalui :

Sambungan Rumah :

- Porsentase $(\%) \quad=70 \%$ (standar kebutuhan air)

- Jumlah jiwa yang terlayani $=70 \% \times 3431$ Jiwa $=2401$ Jiwa

- Asumsi 1 SR = 5 Jiwa (Standar kebutuhan air)

- Jumlah Sambungan Rumah $=\frac{\text { Jumlah jiwa terlayani }}{5 \text { jiwa }}=\frac{2401}{5}=480$ Unit

Hidran Umum :

- Porsentase (\%)

- Jumlah jiwa yang terlayani

- Asumsi $1 \mathrm{HU}$

$=30 \%$ (standar kebutuhan air)

$=30 \%$ x 3431 Jiwa $=1029$ Jiwa

$=100$ Jiwa (Standar kebutuhan air)

- Jumlah Hidran Umum

Penduduk yang dilayani

$=\frac{\text { Jumlah jiwa terlayani }}{100 \text { jiwa }}=\frac{1029}{100}=10$ Unit

= Jiwa terlayani SR + Jiwa terlayani $H U$

$=2401+1029=3431$ jiwa

3. Tingkat Pelayanan

$$
\begin{gathered}
=\frac{\text { penduduk yang dilayani }}{\text { jumlah penduduk }} \times 100 \\
\frac{3431}{3431} \times 100=100 \%
\end{gathered}
$$

4. Asumsi Kebutuhan Air

Sambungan Rumah (lt/org/Hr) $=100$ (standar kebutuhan air)

Hidran Umum (lt/org/Hr) $=30$ (Standar kebutuhan air

Total Kebutuhan Domestik Kategori IKK

$$
\begin{array}{lll}
\mathrm{Q}_{\text {domestik }} & = & (\mathrm{SR}(\mathrm{ltr} / \mathrm{org} / \mathrm{Hr}) \times(\text { Jiwa terlayani SR })+(\mathrm{HU}((\mathrm{ltr} / \mathrm{org} / \mathrm{Hr}) \times \mathrm{Jiwa} \text { Terlayani HU }) \\
\widetilde{\mathrm{Q}}_{\text {domestik }} & = & (100 \times 2401)+(30 \times 1029) \\
\widetilde{\mathrm{Q}}_{\text {domestik }} & = & 271104 \mathrm{lt} / \mathrm{hr}=3,14 \mathrm{l} / \mathrm{det}
\end{array}
$$

Total Kebutuhan Non Domestik Kategori kota kecil 
$\mathrm{Q}_{\text {non domestic }} \quad=\quad(20 \%-30 \%) \times$ Kebutuhan Domestik

$\widetilde{\mathrm{Q}}_{\text {non domestic }} \quad=\quad 20 \% \times 271104$

Q $\quad=54203 \mathrm{lt} / \mathrm{hr}=0,63 \mathrm{l} / \mathrm{det}$

Total Kebutuhan Air

$$
\begin{array}{lll}
\mathrm{Q}_{\text {Total }} & = & Q_{\text {domestik }}+Q_{\text {non domestic }} \\
\tilde{Q}_{\text {Total }} & = & 271104+54203 \\
\widetilde{Q}_{\text {Total }} & = & 325217 \mathrm{lt} / \mathrm{hr}=3,76 \mathrm{l} / \mathrm{det}
\end{array}
$$

Kebutuhan Air Rata - Rata

$$
\begin{array}{lll}
\text { Qr } & = & \text { QDOMESTIK }_{\text {DOMNON DOMESTIK }}+\text { KA (dari Qr) } \\
\operatorname{Qr}(1-0,2) & = & \text { Q QDOMESTIK }_{\text {Q Q }} \text { NON DOMESTIK }+20 \% \mathrm{Qr} \\
\operatorname{Qr} & = & \frac{\text { QDOMESTIK }_{\text {QNON DOMESTIK }}}{0,8} \\
\operatorname{Qr} & = & \frac{43,76}{0,8}=4,71
\end{array}
$$

Kehilangan Air

$$
\begin{array}{ll}
\text { KA } & =20 \% \times \text { Qr } \\
\text { KA } & =20 \% \times 4,71 \\
\text { KA } & =0,941 \mathrm{t} / \text { det }
\end{array}
$$

Kebutuhan Hari Maksimum

$$
\begin{array}{cll}
\text { Qmax } & = & \text { Fmax.Qr } \\
\underset{\text { Qmax }}{\text { Qmax }} & = & 1,15 \cdot 4,71 \\
\text { Kebutuhan Jam Puncak } & = & 5,41 \text { liter } / \mathrm{dt} \\
\mathrm{C} 1 \times \mathrm{Qr}=1,5 \times 4,71=7,06
\end{array}
$$

Dari Hasil perhitungan proyeksi kebutuhan air pada tahun 2032 atau pada akhir periode perencanaan Pada Tabel 4.5 Total kebutuhan air di masing - masing desa yaitu untuk desa Dakaino sebesar 3,76 1/det, Desa Akedaga 4,39 1/det, Desa Toboino sebesar 1,97 l/det , Desa Dodaga sebesar 3,68 1/det, Desa Tutuling Jaya 2,52 1/det dan desa Woka jaya sebesar 1,28 1/det. Sehingga kebutuhan total untuk Kecamatan Wasile Timur sebesar 17,61 1/det. Data yang dibutuhkan untuk analisis jaringan distribusi yaitu data kebutuhan air pada jam puncak yaitu kebutuhan air yang didapat dari hasil kebutuhan air rata - rata di kalikan dengan faktor jam puncak $(1,5)$. Pada Tabel 4.5 di atas didapat hasil perhitungan Kebutuhan air pada jam puncak di masing - masing desa yaitu Desa dakaino sebesar 7,06 1/det, Desa Akedaga sebesar 8,24 1/det, Desa Toboino sebesar 3,70 1/det, Desa Dodaga sebesar 6,90 Desa Tutuling Jaya sebesar 4,72 l/det dan Desa Woka Jaya sebesar 2,40 l/det jadi total kebutuhan jam puncak di kecamatan wasile timur pada akhir periode perencanaan sebesar 33,01 1/det.

\subsection{Analisa Jaringan Distribusi menggunakan Epanet 2.0}

Analisa jaringan distribusi dengan program Epanet memerlukan data bentuk Topografi lokasi yang akan di analisis,data topografi tersebut digunakan untuk mengetahui sistem pengaliran yang akan digunakan dan membuat peta jaringan pipa yang akan di analisis. Hasil dari analisa menggunakan program Epanet yaitu pressure pada tiap - tiap junction/node,kecepatan aliran dalam pipa, debit air didalam pipa dan diameter pipa yang digunakan. Hasil dari analisa jaringan distribusi yang direncanakan harus memenuhi kriteria jaringan distribusi menurut Kep Men PU No.18 Tahun 2007
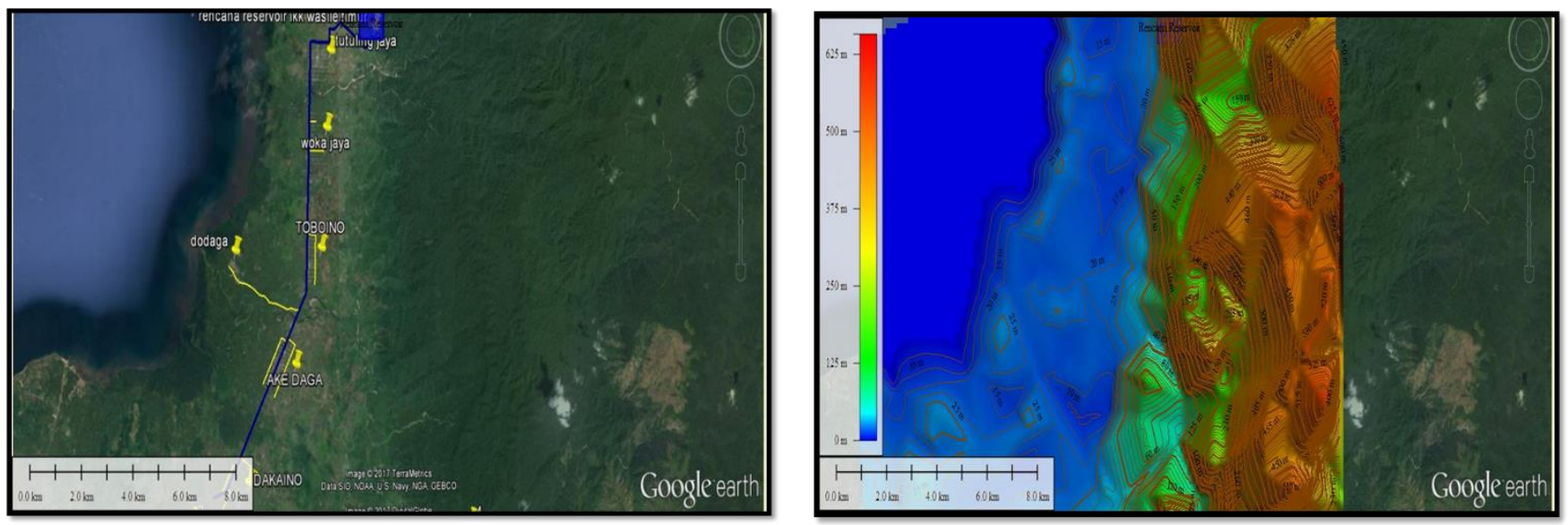
(a)

(b)

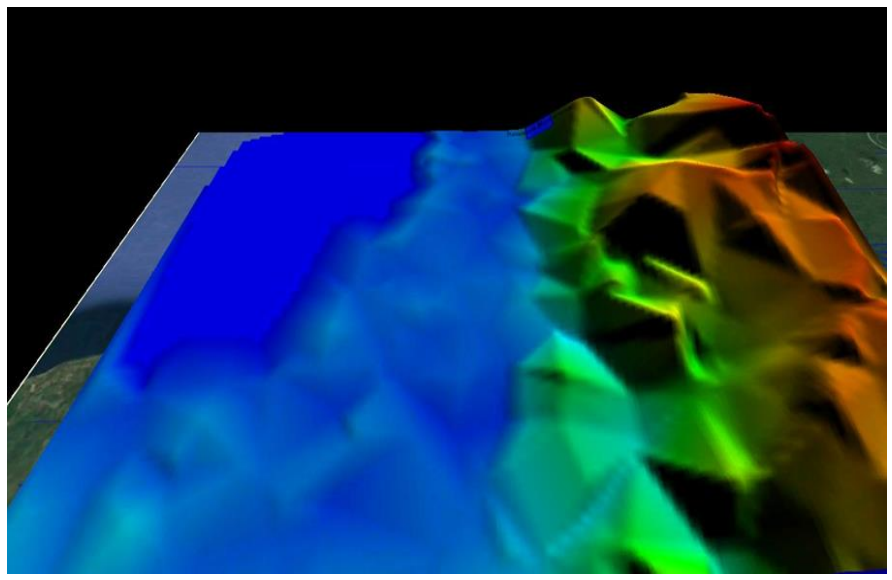

(c)

Gambar 3 (a) Peta jaringan, (b) \& (c) Bentuk Topografi Kecamatan Wasile Timur

Dari Gambar 3b dan 3c dapat dilihat bahwa beda tinnggi antara daerah pelayanan dengan reservoir cukup signifikan dimana lokasi reservoir berada pada elevasi 65 mdpl sedangkan daerah pelayanan berada di rata - rata 15 mdpl dengan bentuk yang relatif datar sepanjang daerah pelayanan. setelah diketahui bentuk topografi dimana sumber air baku berada lebih tinggi dari pada daerah pelayanan maka dalam analisa jaringan distribusi pada SPAM IKK Wasile Timur menggunakan sistem Pengaliran Gravitasi Dimana Air bersih didistribusikan ke daerah pelayanan dengan memanfaatkan tenaga/tekanan gaya gravitasi pada daerah tersebut. Pipa yang digunakan untuk jaringan distribusi yaitu dengan menggunakan pipa HDPE untuk mengurangi Headloss/kehilangan tekanan. Pipa HDPE terbuat dari bahan plastik polyethylene dan mempunyai koefisien kekasaran 140 - 150, nilai koefisien tersebut digunakan untuk mengisi data pipa pada program Epanet. Hasil analisa bisa dilihat pada gambar 4 sampai gambar 5 .
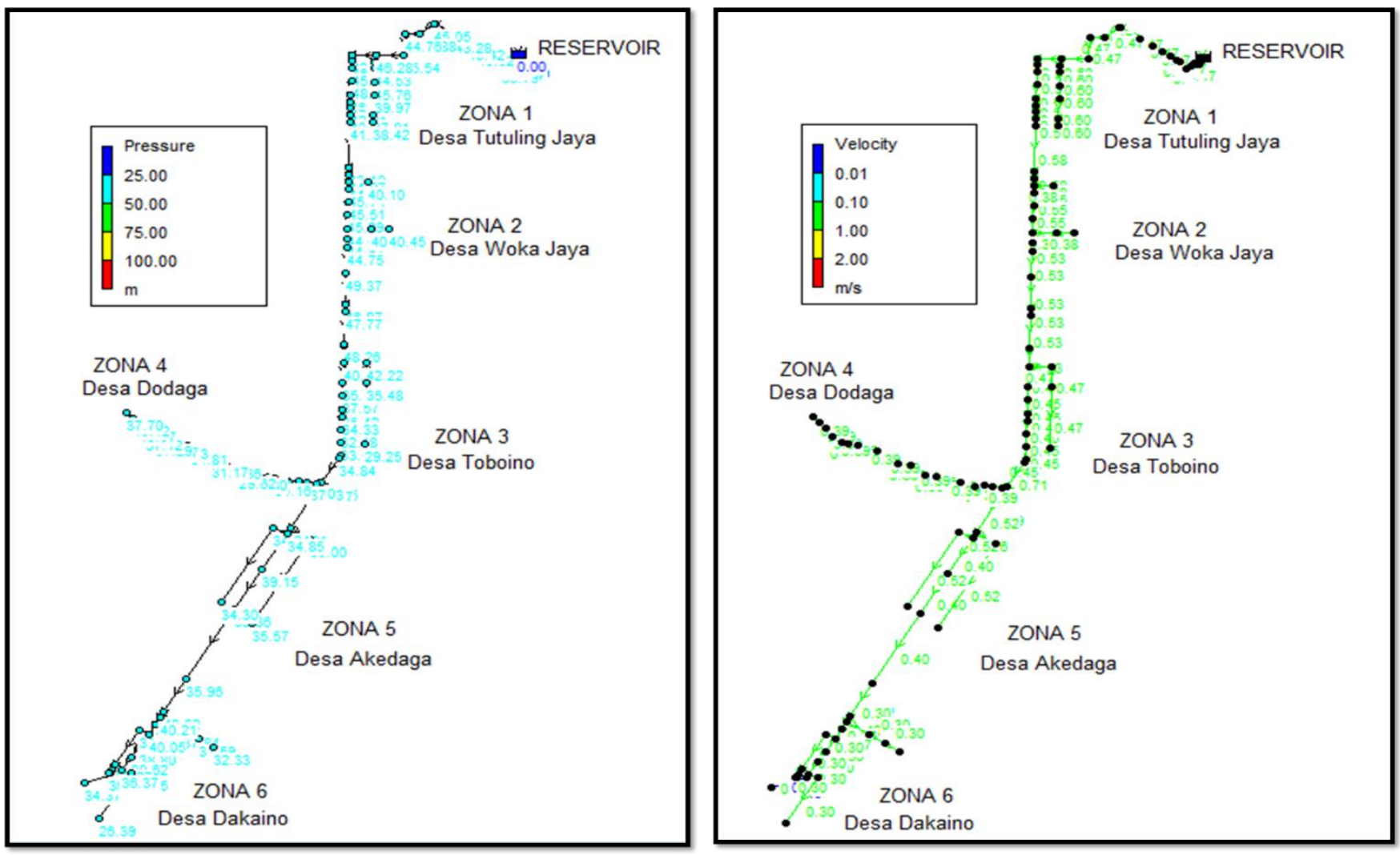
(a)

(b)

Gambar 4 (a). Pressure dan (b) Velocity Hasil Analisa Program Epanet

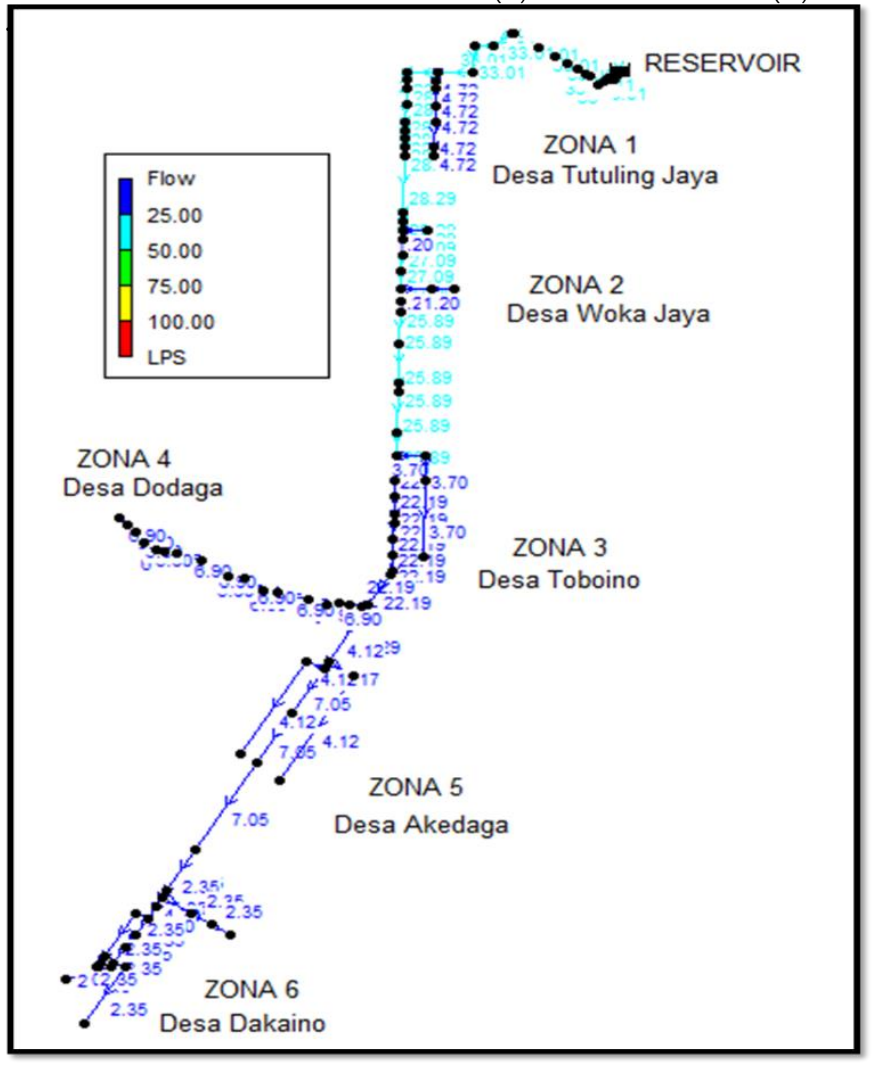

(a)

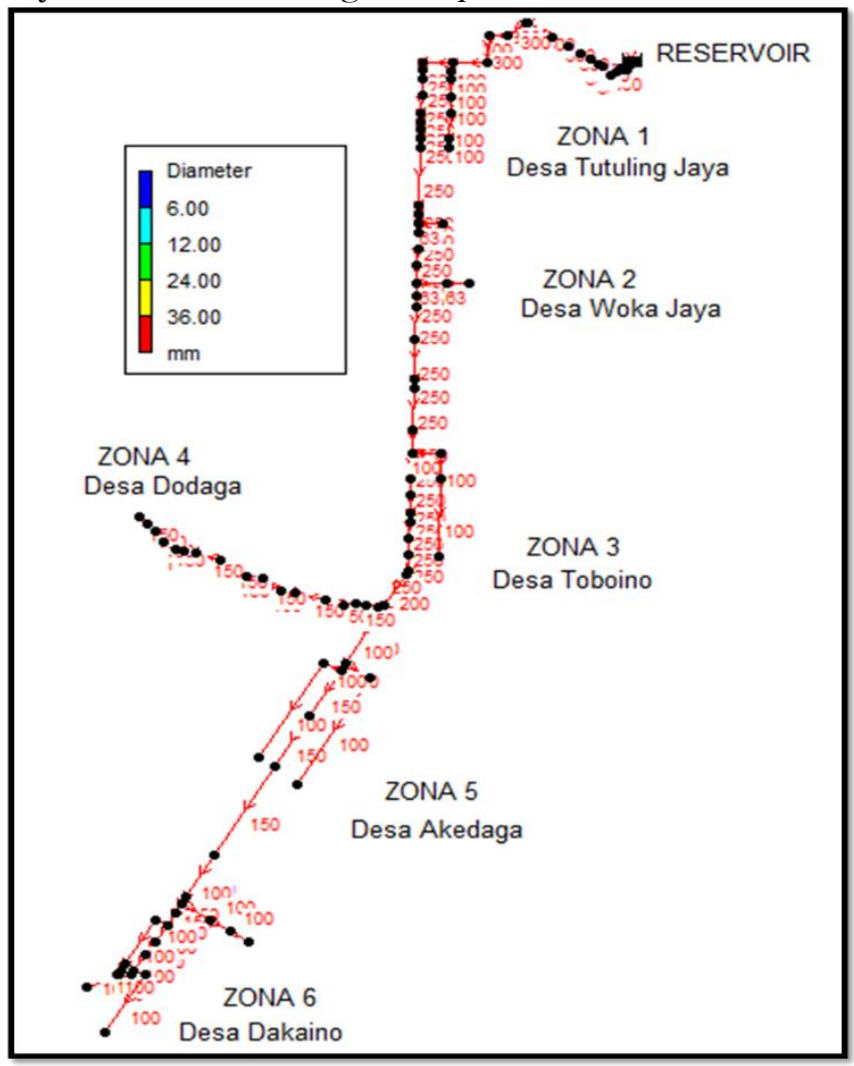

(b)

Gambar 5 (a) Debit air dalam Pipa dan (b) Diameter Pipa Hasil Analisis Program Epanet

Dari gambar 4a menunjukkan bahwa tekanan maksimum sebesar 49,37 m atau sama dengan 4,937 Bars sedangkan Tekanan minimum sebesar 26,39 m atau sama dengan 2,639 bars tekananan hasil analisis masih memenuhi kriteria perencanaan jaringan distribusi yaitu untuk tekanan maksimum 9,0-12,4 bars atau sama dengan $90-$ 124 meter sedangkan tekanan minimum yang di ijinkan dilihat dari tabel kriteria perencanaan yaitu $0,5-1,0$ bar untuk ujung pipa terjauh. Gambar 4b menunjukkan kecepatan aliran maksimum sebesar 0,60 m/det dan kecepatan minimum sebesar $0,30 \mathrm{~m} /$ det untuk ketentuan kecepatan aliran dilihat dari Tabel kriteria perencanaan yaitu minimum $0,25 \mathrm{~m} /$ det dan kecepatan maksimum $2,5 \mathrm{~m} /$ det jadi untuk kecepatan aliran masih memenuhi kriteria perencanaan

Total kebutuhan air yang masuk di desa - desa maupun total kebutuhan air yang keluar dari reservoir dilihat pada Gambar 5a sesuai dengan Total kebutuhan jam puncak hasil perhitungan proyeksi kebutuhan air pada tahun 2032 yaitu sebesar 33,01 1/det. Diameter pipa yang digunakan pada Gambar 4b dapat diihat pada tabel 10 dan 11.

Tabel 10 Rekapitulasi Pipa Distribusi Utama Hasil Analisa Program Epanet 2.0

\begin{tabular}{ccc}
\hline $\begin{array}{c}\text { Diameter Pipa } \\
(\mathbf{m m})\end{array}$ & $\begin{array}{c}\text { Panjang Pipa } \\
\text { (Meter) }\end{array}$ & $\begin{array}{c}\text { Panjang Pipa } \\
(\mathbf{K M})\end{array}$ \\
\hline $\mathbf{3 0 0}$ & 3142,81 & 3,143 \\
$\mathbf{2 5 0}$ & 6337,77 & 6,338 \\
$\mathbf{2 0 0}$ & 129,42 & 1,30 \\
$\mathbf{1 5 0}$ & 2665,69 & 2,666 \\
\hline
\end{tabular}




\begin{tabular}{ccc}
\hline $\mathbf{1 0 0}$ & 3403,68 & 3,404 \\
Total & $\mathbf{1 5 6 7 9 , 3 7}$ & $\mathbf{1 5 , 6 8 0}$ \\
\hline
\end{tabular}

Tabel 11 Rekapitulasi Panjang Pipa Pada Jaringan Distribusi Utama Dan Distribusi Bagi

\begin{tabular}{lcc}
\hline Uraian & $\begin{array}{c}\text { Panjang Pipa } \\
\text { (Meter) }\end{array}$ & $\begin{array}{c}\text { Panjang Pipa } \\
(\mathbf{K M})\end{array}$ \\
\hline Jaringan Distribusi Utama & 15679,37 & 15,680 \\
Jaringan Distribusi Bagi & 13160 & 13,160 \\
Total & $\mathbf{2 8 8 3 9 , 3 7}$ & $\mathbf{2 8 , 8 4 0}$ \\
\hline
\end{tabular}

Pada Tabel 10 dan 11 menujukkan bahwa diameter pipa yang digunakan Bervariasi dengan Total panjang keseluruhan 28.839 meter atau sama dengan $28,840 \mathrm{~km}$.

\subsection{KESIMPULAN}

Dari pembahasan analisa hidrolis jaringan distribusi utama dan distribusi bagi pada sistem penyediaan air minum (SPAM) IKK Wasile Timur sebagaimana di uraikan sebelumnya maka ada beberapa hal yang dapat di simpulkan yaitu :

1. Dari hasil pemetaan jaringan distribusi utama dan distribusi bagi pada sistem penyediaan air minum (SPAM) IKK Wasile Timur terbagi menjadi 6 Zona Pelayanan, Zona 1 yaitu Desa Tutuling Jaya, Zona 2 Desa Woka Jaya, Zona 3 yaitu Desa Toboino, Zona 4 Desa Dodaga, Zona 5 Desa Akedaga dan Zona 6 Desa Dakaino.

2. Kebutuhan air untuk tahun 2032 yaitu untuk Desa Dakaino Sebesar 7,06 1/det, Desa Akedaga 8,24 1/det, Desa Toboino 3,70 l/det Desa Dodaga 6,90 l/det Tutuling Jaya 4,72 1/det dan Woka Jaya 2,40 1/det.Jadi Total kebutuhan air untuk kecamatan Wasile Timur sampai proyeksi tahun 2032 yaitu sebesar 33,01 1/det. Debit sumber air baku sebesar 1,043 m3/det atau 1.043 l/det jadi masih sangat mencukupi untuk dimnfaatkan sampai dengan tahun 2032.

3. Diameter pipa yang digunakan yaitu diameter $300 \mathrm{~mm}, 250 \mathrm{~mm}, 200 \mathrm{~mm}, 150 \mathrm{~mm}, 100 \mathrm{~mm}$, dan $63 \mathrm{~mm}$. Dari variasi Pipa tersebut didapat Tekanan Maksimum 49,37 m atau sama dengan 4,937 Bar sedangkan Tekanan minimum sebesar 26,39 $\mathrm{m}$ atau sama dengan 2,639 bar. Tekanan dari hasil analisis memenuhi kriteria perencanaan jaringan distribusi yaitu maksimum 9,0 - 12,4 bar dan minimum 0,5 - 1,0 bar. Kecepatan aliran Maksimum sebesar 0,60 m/det dan kecepatan minimum sebesar $0,30 \mathrm{~m} /$ det kecepatan aliran pada hasil analisa memenuhi kriteria perencanaan dimana menurut ketentuan yaitu maksimum 2,5 m/det dan minimum sebesar $0,25 \mathrm{~m} /$ det.

\section{References}

[1] BPS. 2017. Wasile Timur Dalam Angka, Halmahera Timur.

[2] Halim, Fuad. 2016. Perencanaan sistem Jaringan Distribusi Air Bersih di kelurahan pangolombian kecamatan tomohon selatan.jurnal sipil static Vol. 4 No.2, Universitas Sam Ratulangi, Manado

[3] Ikhsan, 2003. Study Pemenuhan Kebutuhan Air Bersih PDAM Kota Surabaya

[4] Tahun Proyeksi (2015). NEUTRON, Vol.3, No. 1.Surabaya

[5] Nelwan,wuisan dan Tanudjaja, 2013. Perencanaan Jaringan Air bersih desa kima bajo kecamatan Wori, Jurnal Sipil Statik Vol.1 No.10, universitas Sam ratulangi, Manado.

[6] Rahayu, Prima K.S. 2011. Perencanaan jaringan perpipaan penyediaan air Bersih mandiri di kecamatan beji kabupaten pasuruan, Institut Teknologi Sepuluh November, Surabaya.

[7] Ramadhan, 2014. Analisa hidrolika sistem jaringan distribusiair minum di komplek perumahan PT. PUSRI PALEMBANG Menggunakan Epanet 2.0, Jurnal Teknik Sipil dan Lingkungan Vol.2.No.3, Universitas Sriwijaya 
Rossman. L.A. 2000. Epanet 2 User Manual, EKAMITRA Engineering

[9] Sudirman, Andry. 2012. Analisa Pipa Jaringan Distribusi air bersih di kabupaten Maros dengan menggunakan softwere epanet 2.0, Universitas Hasanudin, Makassar

[10] Tata, G.M. 2014. Rencana Induk Pengembangan Sistem Penyediaan Air Minum Kota Ternate, PDAM , Ternate.

[11] Triatmodjo,Bambang. 2009. Hidraulika II Beta offset, Yogyakarta.

[12] Yosefa dan indarjanto, 2017. Analisis Perencanaan dan Pengembangan Jaringan Distribusi Air Bersih di PDAM Tulungagung, Jurnal Teknik Its Vol. 6, No. 1, Institute Teknologi Sepuluh November, Surabaya. 